\title{
OSB and Marine Plywood: Performance Comparison for use with Light Steel Frame Walls in Brazil
}

\author{
Max Junginger ${ }^{1}$, Maurício M. Resende ${ }^{2}$, \\ Luciana A. Oliveira ${ }^{3}$ and Vanderley M. John ${ }^{4}$
}

\author{
${ }^{1}$ Polytechnic School, University of São Paulo, São Paulo, SP, Brazil. maxjgg@gmail.com \\ ${ }^{2}$ São Judas Tadeu University, São Paulo, SP, Brazil, Rua Taquari, 546, mauresende@yahoo.com \\ ${ }^{3}$ Inst. de Pesq. Tecnológicas, São Paulo, SP, Brazil, Av. Prof. Almeida Prado, 532, Luciana@ipt.br \\ ${ }^{4}$ Polytechnic School, University of São Paulo, São Paulo, SP, Brazil, Vanderley.John@lme.pcc.usp.br
}

\begin{abstract}
The use of light steel frame and wood frame in Brazil is still recent, hence there is little information about the durability of these technologies applied in Brazilian climate conditions. The wood-based boards are used as a part of the light steel or wood frame walls and are designed to contribute to the wall structural behavior (horizontal reinforcement and resistance to suspended loads). Once the information if such boards meet the DL (design life) set in the Brazilian code of residential building performance is still unknown, this paper analyses the technical characteristics of two woodbased boards - OSB and marine plywood - aiming to gather more information concerning durability under liquid water action. Thus, tests were carried out on samples of these two boards to evaluate their behavior against liquid water and after accelerated ageing test. In all cases, OSB showed to be more sensitive to early degradation than plywood.
\end{abstract}

Keywords: OSB, Marine Plywood, Durability, Light Steel Frame.

\section{Introduction}

The use of light steel frame and wood frame in Brazil is still recent. The first researches and publications were conducted in the last decade (Crasto, 2005; Milan, Novello, and Dos Reis, 2011; Oliveira and Mitidieri Filho, 2011; SiNAT, 2016), because of that there is little information about the durability of these technologies applied in Brazilian climate conditions, which can be around $23^{\circ} \mathrm{C}$ and $76 \%$ of relative humidity $(\mathrm{RH})$ in the South East, with an monthly average solar radiation between 16 and $24 \mathrm{MJ} / \mathrm{m}^{2}$.day (Tiba, 2000).

Wood-based boards are used as a part of the light steel frame or light wood frame walls. Mostly, the outer part of these external walls is formed by four layers (from exterior to interior): basecoat (mortar-based layer around $6 \mathrm{~mm}$ thick), cementitious board, weather resistive barrier (sheathing membrane) and wood-based board (OSB or marine ${ }^{1}$ plywood), the last one improving the wall structural behavior (Campos, 2014; Rego, 2012). The basecoat is directly

\footnotetext{
${ }^{1}$ In Brazil there is no standard setting the minimum requirements for plywood; however, there are two main types of plywood in the market: one used for making wood-based products, like cabinets (simply called "plywood") and another one, known as "marine plywood", used in situations where the presence of liquid water and high levels of relative humidity are rather frequent, like in boat hulls; hence the designation "marine" before the word plywood. According to APA (www.apawood.org), a product like that could receive the classification "APA marine". The boards used in this paper were supplied by a big manufacturer in Brazil.
} 
adhered to the cementitious board, which is fastened (screws) to the OSB with the sheathing membrane in between. Also, in Brazil is quite common to have a wood-based board (usually OSB) at the inner side of the wall right behind the gypsum board as a way of improving the wall resistance to suspended loads; since shelves, frames and other loads can be fastened everywhere, whether there is a steel stud or not, a continuous layer is a need.

In terms of durability, the outer board might be directly affected by the wind-driven rain and the inner board by the high level of relative humidity $(\mathrm{RH})$ inside the building. Water vapor movement is a matter of vapor pressure and it normally goes from outside to inside during the summer and from inside to outside during the winter (for cold countries). But the thing is not as "simple" as that, since there is no requirement for airtightness of light steel frame walls in Brazil: penetrations, holes and electrical fixtures are not sealed. Hence, air leakage (exfiltration) might be so high that the use of vapor barriers on the inner part of exterior walls is useless and a waste of money. To sum up with, knowing that keeping windows open is a cultural behavior in Brazil, the RH inside the house is probably close to the RH outside during warm seasons, which means that, basically speaking, RH all around the wall will be like the exterior RH. There might be some exceptions, though, mainly during the winter in southern cities, but in any case, interior air conditions are uncontrolled most of the time. A deeper discussion about this subject is out of the scope of this text, but it can be found elsewhere (Quirouette, 1985; Straube, 2002; Kumaran, 2009; Lstiburek, 2009; NRC, 2015; ABCB, 2016).

According to ABNT NBR 15575 (ABNT, 2013), Brazilian code of residential building performance, the design life (DL) of the main structural elements (steel and wood profiles) and of the other elements whose maintenance is not easy is at least 50 years. Since the wood-based
layer contributes to the wall structural behavior and its maintenance is quite laborious, the
design life (DL) of it should be equivalent to that of the main structurgl clements (steel and
wood studs).
Once the information if such boards meet this DL in Brazilian climate is still unknown, this

paper analyses the technical characteristics of two wood-based boards-OSB and marine

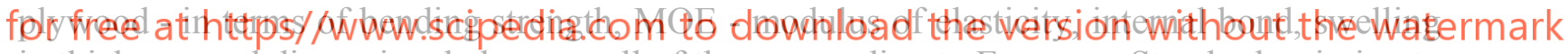
in thickness and dimensional changes, all of them according to European Standards, aiming to get more information concerning durability of these boards when subjected to liquid water action. Thus, tests were carried out on samples of these two boards to evaluate their behavior before and after accelerated ageing tests.

\section{Experimental Work}

Samples of OSB (11.1 mm thick, OSB/3 (APA, 2017) and marine plywood (12 mm thick) were tested according to EN standards to gather information about density, EN 323 (CEN, 1993a); moisture content, EN 322 (CEN, 1993b); swelling in thickness, EN 317 (DIN, 1993); bending strength and modulus in bending, EN 310 (BSI, 1993a); internal bond, EN 319 (BSI, 1993b); dimensional changes, EN 318 (BSI, 2002a) and moisture resistance, EN 321 (BSI, 2002b).

EN standards were used because there is no Brazilian standard about the subject; in addition, regardless of having their own specific standards, samples of plywood were also tested according to OSB standards so that mechanical properties can be compared under the same conditions.

Such mechanical properties were measured for both axis: major strength ( $\mathrm{L}=$ longitudinal) 
and minor strength $(\mathrm{T}=$ transversal) using a universal testing machine (EMIC DL 10000). To determine the properties related to dimensional changes, a climatic chamber (model Thermotron 2800 programable controller) was used.

For each panel type, $1050 \times 50 \mathrm{~mm}$ samples were used for internal bond and swelling in thickness; $1050 \mathrm{~mm}$ wide samples for bending properties and ageing and 4 (four) $50 \mathrm{~mm}$ wide samples for dimensional changes. For the sake of simplicity, the terms mass and weight will be used interchangeably in this text.

\subsection{Results and Discussion}

\subsubsection{Properties of the boards}

After reaching constant mass at $21{ }^{\circ} \mathrm{C}$ and $65 \% \mathrm{RH}$, the main properties of the boards were evaluated, and the results can be seen in Table 1.

Table 1. OSB and marine plywood properties (average).

\begin{tabular}{cccccc}
\hline Board type & Density $\left(\mathrm{kg} / \mathrm{m}^{3}\right)$ & Layers & MC $(\%)$ & MOE $\left(\mathrm{N} / \mathrm{mm}^{2}\right)$ & BS $\left(\mathrm{N} / \mathrm{mm}^{2}\right)$ \\
\hline OSB & $639.9 \pm 24.6$ & Homogeneous & $10.5 \pm 0.3$ & $4607 \pm 649$ & $32.7 \pm 6.4$ \\
\hline Plywood & $623.9 \pm 20.9$ & Five & $10.3 \pm 0.4$ & $7039 \pm 559$ & $60.3 \pm 8.6$ \\
\hline MC - moisture content & BS - bending strength & MOE - modulus of elasticity
\end{tabular}
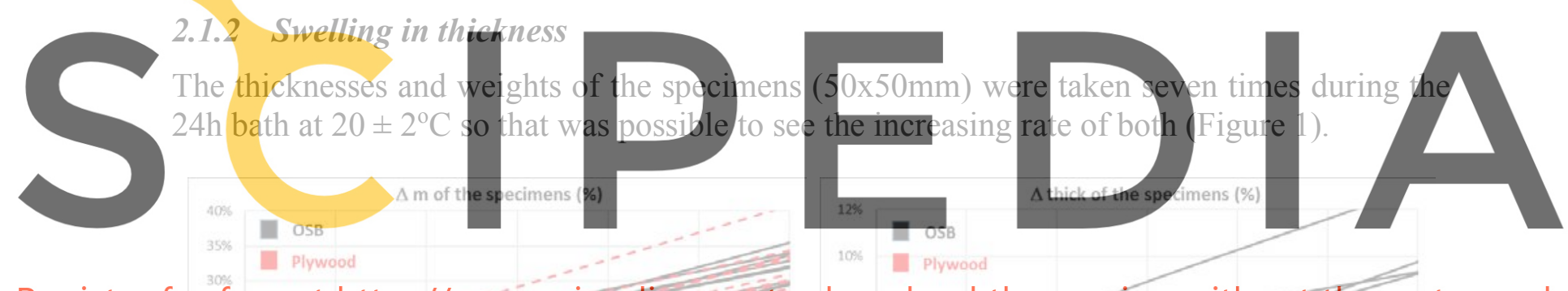

Register for free at https//WWWW-scipedia.com to download the yersion withouthe watermark
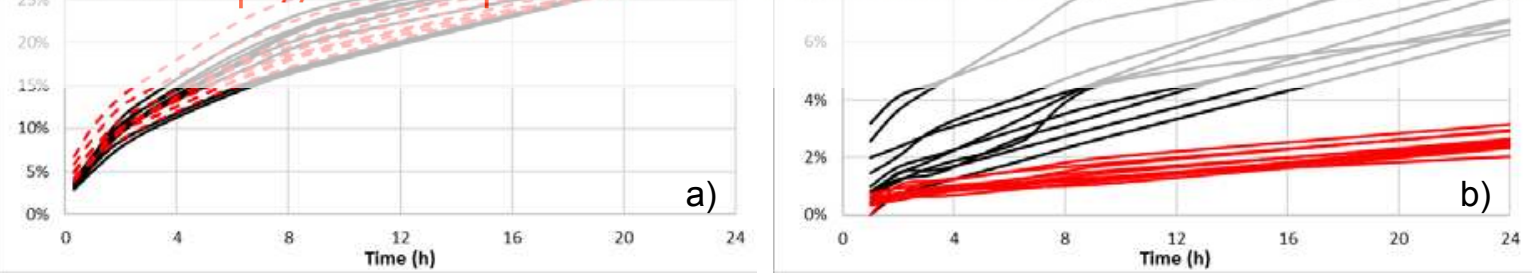

Figure 1. Changes in the a) weights and b) thicknesses of OSB and plywood for the first 24 hours.

In Figure 2 is possible to see the total thickness of all the specimens when put together side by side. It is rather evident the difference between OSB and plywood.

After the first $24 \mathrm{~h}$ of the soak bath, all the specimens were kept under water for more $24 \mathrm{~h}$ and, then, remained inside a room at $20 \pm 2{ }^{\circ} \mathrm{C}$ and uncontrolled $\mathrm{RH}$ levels (around 55\%) for a drying session. The results are shown in Figure 3 and here it is important to notice that the moisture content is related to the initial weight of the specimens, not to oven-dry weight. It is possible to see that both OSB and plywood show almost the same wetting and drying curves and practically the same water uptake coefficient (note that $\mathrm{X}$-axis is the square root of time). 

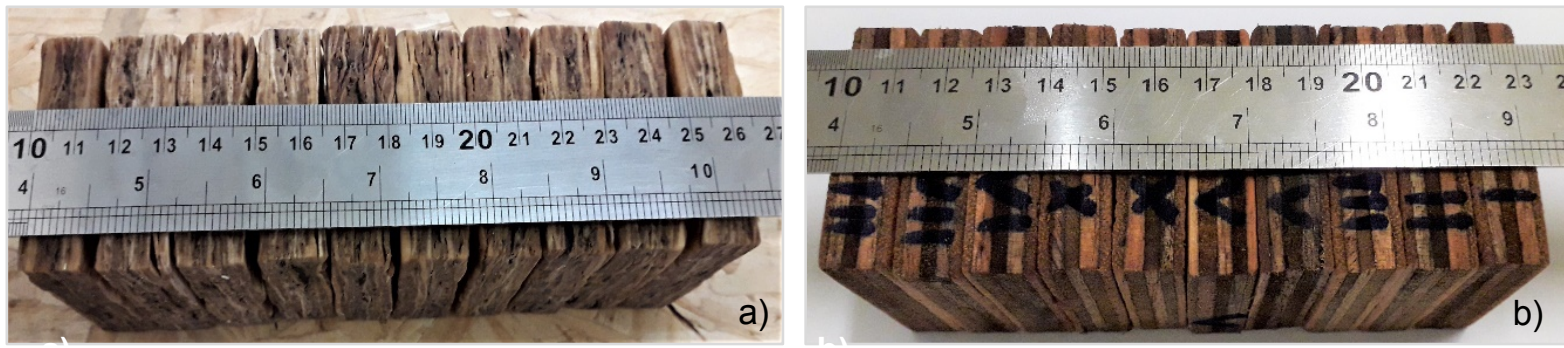

Figure 2. Appearance of a) OSB and b) Plywood after swelling.

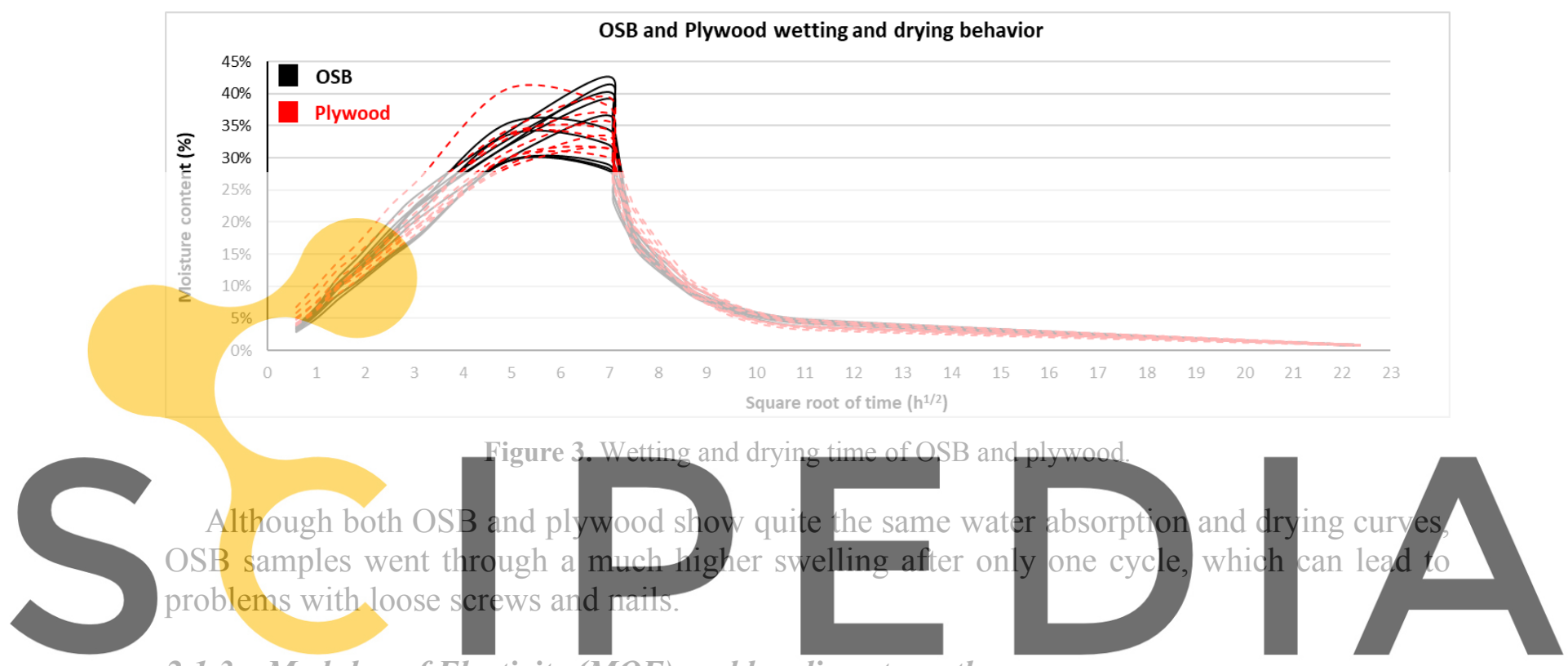

\subsubsection{Modulus of Elasticity (MOE) and bending strength}

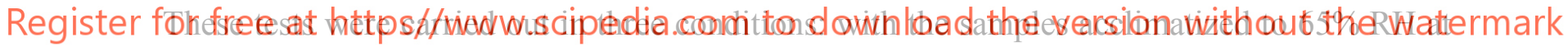
$21^{\circ} \mathrm{C}$ (Natural), after cyclic test (Aged) EN 321 (BSI, 2002b) and with the samples after 24h under tap water (Soak). For each set, 10 specimens were tested, which meant a total of 120 specimens (two boards, three conditions, two axis and 10 specimens each).

The distance between the supports was 20 times the thickness, i.e., $222 \mathrm{~mm}$ for OSB and $240 \mathrm{~mm}$ for plywood and both loading head and supports had a diameter of $20 \mathrm{~mm}$. Figure 4 presents the retention rate for MOE and bending strength (BS) for each set according to the axis: L stands for longitudinal and $\mathrm{T}$ stands for transversal (longitudinal means the axis with the highest strength).

Since the mechanical strength is deeply related to the moisture content of the specimens, the moisture contents of OSB and plywood after soak bath were determined as follows: values taken immediately after the bending test and, then, after $48 \mathrm{~h}$ in an oven at $103^{\circ} \mathrm{C}$. So, when soaked, moisture contents (in percentage, oven-dry basis) were $36.9 \pm 2.1$ for OSB and $41.8 \pm 4.0$ for plywood.

All OSB samples presented great deterioration after soaking and cyclic test, so it was difficult to reach good accuracy and precision when measuring the thickness, which means the values presented in Figure 4 vary around $\pm 5 \%$. Mechanical strength loss due to water action is also described by other authors (Kojima and Suzuki, 2011; Korai, Kojima and Suzuki, 2015) 
and the results in this paper are in good agreement with those ones; more similar results are also described by Okino et al (2004), when studying OSB with Brazilian wood strands.
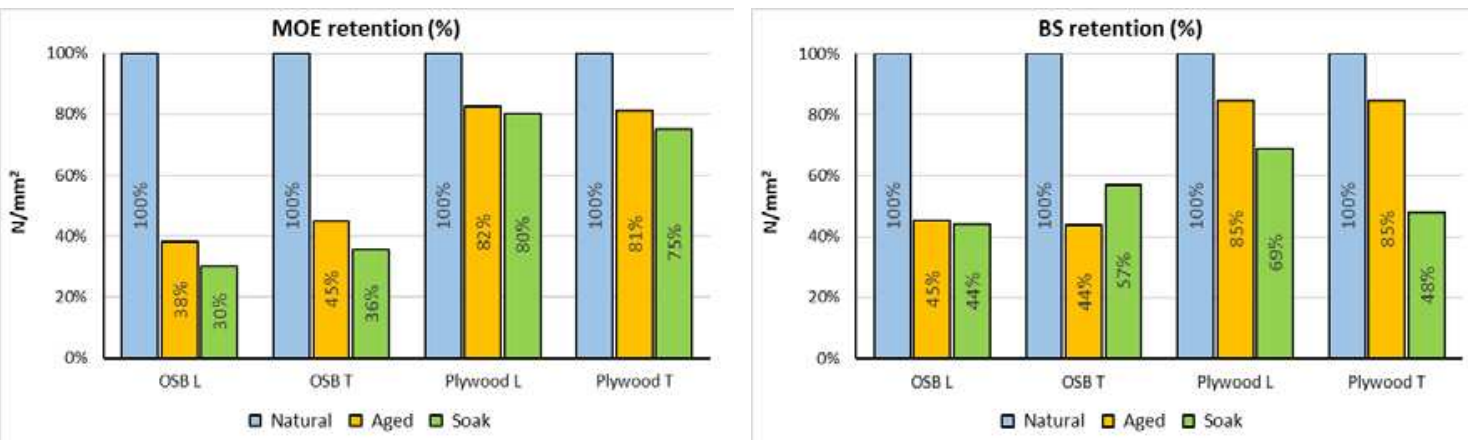

Figure 4. MOE and BS retention rates for OSB and plywood.

\subsubsection{Internal bond}

Internal bond tests were carried out under five circumstances: 1) original board acclimatized at $65 \% \mathrm{RH}, 21^{\circ} \mathrm{C}$ (Natural); 2) after swelling (soak bath); 3) after boiling; 4) oven-dry after swelling and 5) oven-dry after boiling (Figure 6). Specimens in situation 4) and 5) were ovendried for $48 \mathrm{~h}$ after swelling and boiling tests; then, all the samples from 2) to 5) were acclimatized at $65 \% \mathrm{RH}$ and $21^{\circ} \mathrm{C}$ before the internal bond test. Due to the mechanical damage

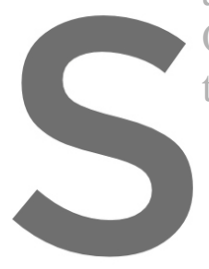
OSB samples went thro to measure their internal bond.
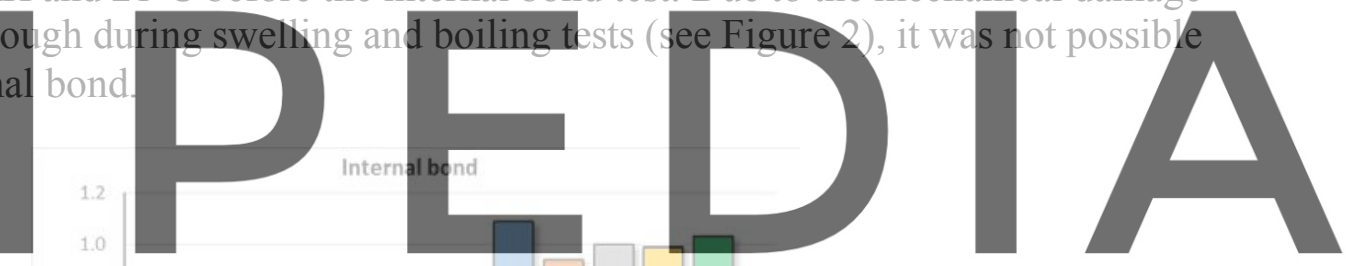

Register for free at https//WWW.scipedia.com to download the version without the watermark

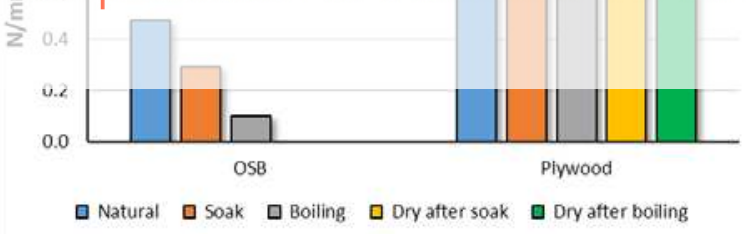

Figure 5. Internal bond of OSB and Plywood under different conditions.

\subsubsection{Dimensional changes}

All the samples in this test had the nominal dimensions of $300 \times 50 \mathrm{~mm}$ and the following charts show the mass of each specimen over time (dashed line, right vertical axis) and also the percentual variation of the mass in the last 24 hours (solid lines, left vertical axis). These last ones are important to see how long the specimens take to reach the equilibrium as required by EN 318 (BSI, 2002a): up to $0.1 \%$ in 24 hours. While Figure 6 shows the result for the cycle 30 65-85, Figure 7 shows the data for the cycle 85-65-30.

All the charts follow the same reasoning as explained here for the cycle 30-65-85: the specimens were taken from room temperature and put into the climatic chamber at $30 \% \mathrm{RH}$. 
After the mass reaches the equilibrium, the $\mathrm{RH}$ level is changed to $65 \%$ and the charts show this as the first bump. Afterwards, the RH level is increased to $85 \%$ and a second bump show up; then, the specimens remain in the chamber until equilibrium.
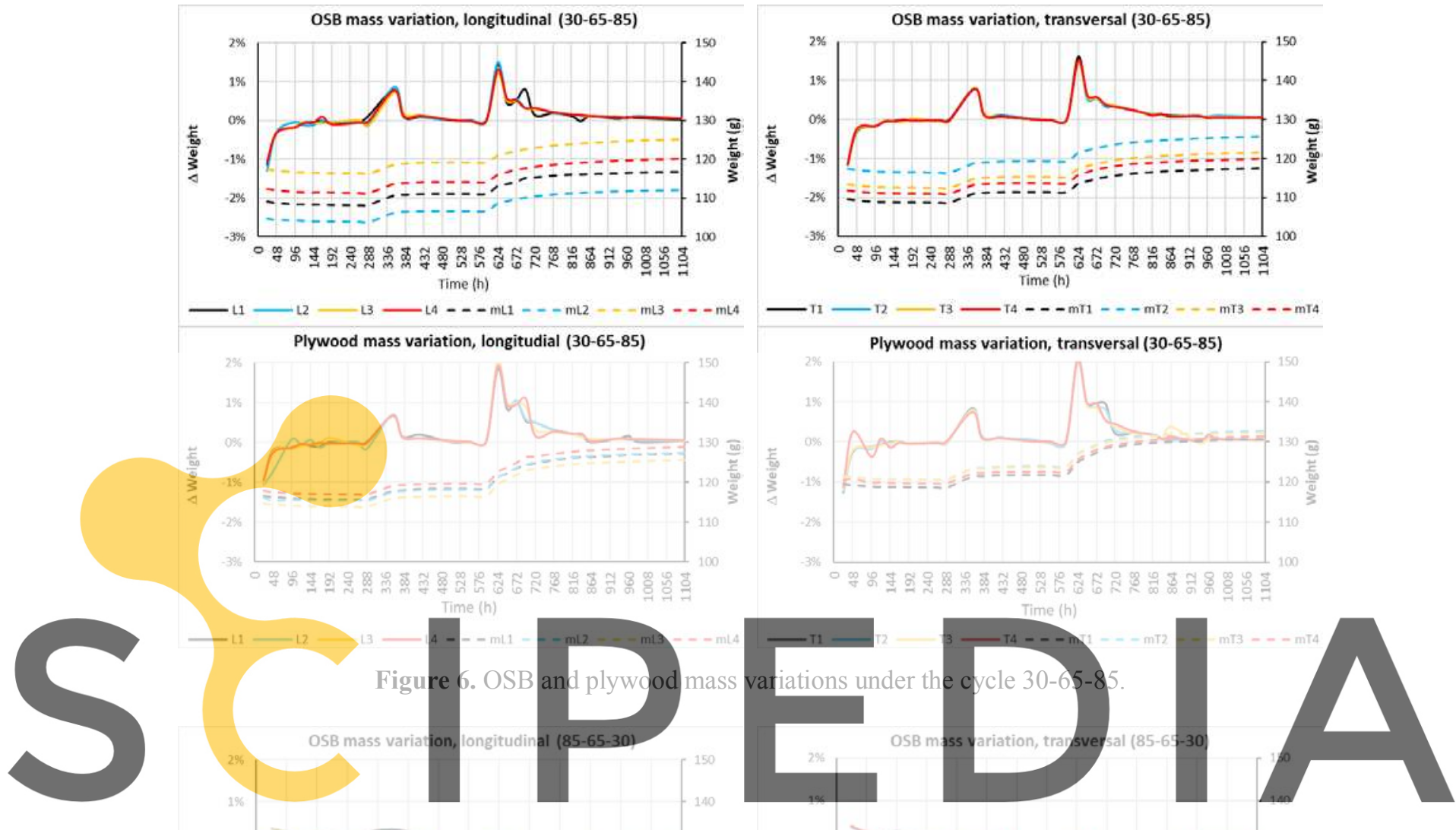

Register for
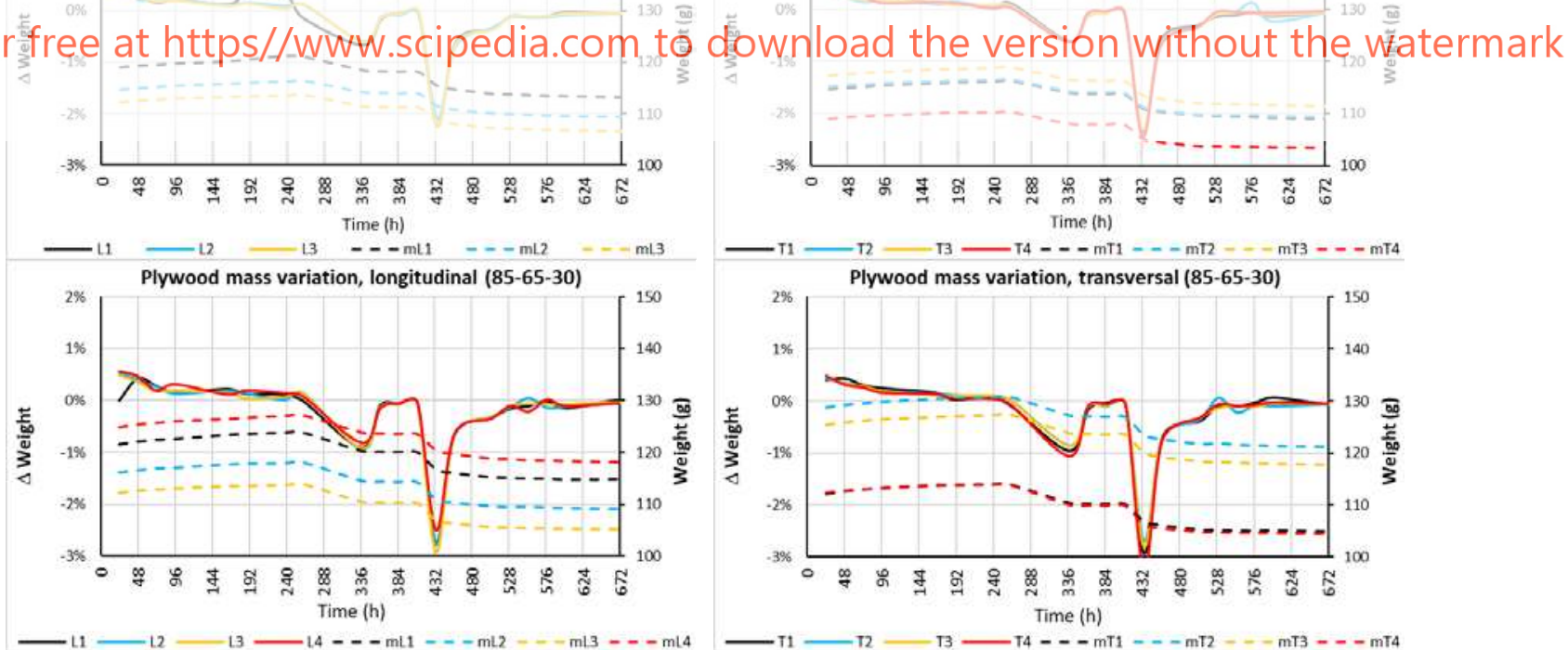

Figure 7. OSB and plywood mass variations under the cycle 85-65-30.

The two following charts, in Figure 8, show the changes of the samples length for both cycles 
as well: set 1 for $\mathrm{L}_{65,85}$ and set 2 for $\mathrm{L}_{65,30 \text {. }}$
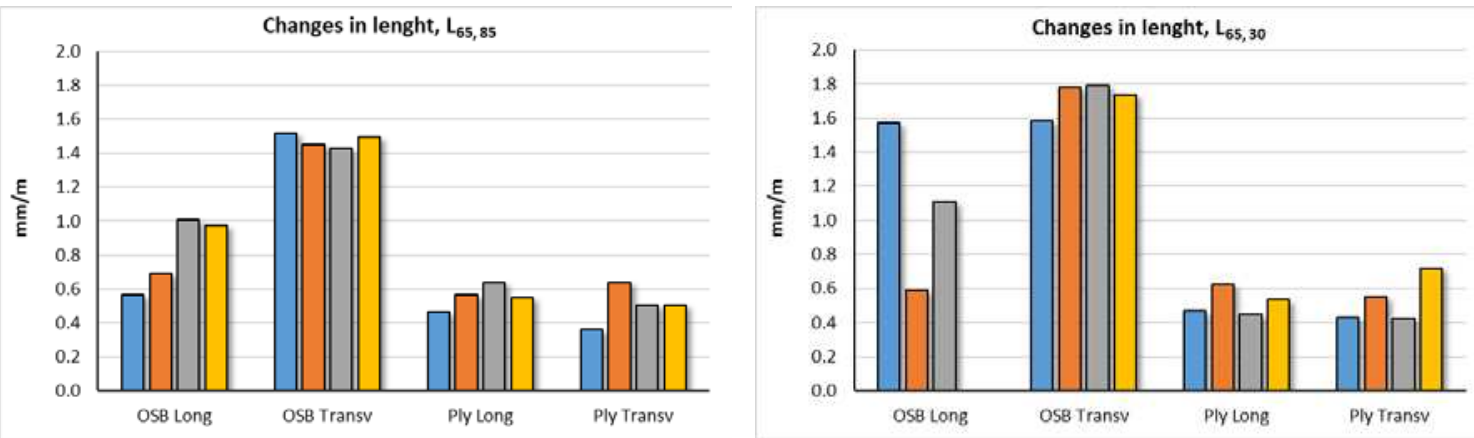

Figure 8. Changes in length of OSB and plywood: $\mathrm{L}_{65,85}$ and $\mathrm{L}_{65}, 30$.

\section{Conclusions}

- Water can reach wood-based boards either due to high levels of relative humidity or because of wind-driven rain infiltration, usually taken as $1 \%$ of the rain load over the wall (ASHRAE, 2016), whether through crackings, openings, sealant failures and so on. Regarding the materials evaluated in this experiment, OSB is much more sensitive to water than plywood. Hence, its low resiliency against the most abundant degradation agent, together with the fact maintenance is not a common action in Brazil, is an alert

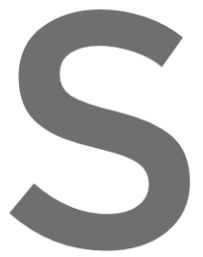
that OSB might not the best than cold countr Even with boar "humid" means only exceeding 85
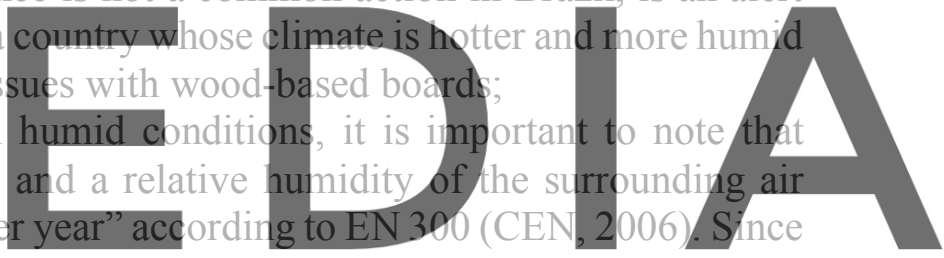

in most cities of Brazil the relative humidity goes beyond this level many weeks per

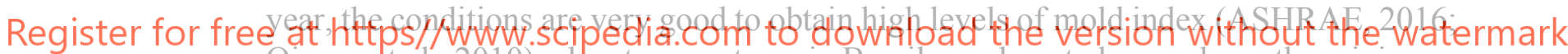
Ojanen et al., 2010); also, temperatures in Brazil are almost always above the minimum threshold for mold growth;

- In all tests OSB showed lower performance when compared to plywood, even where there was no direct contact with liquid water but only with different humidity levels, which means a higher stress level over time due to the greater dimensional changes.

\section{ORCID}

Max Junginger:

Luciana Oliveira:

Maurício Resende:

Vanderley John: https://orcid.org/0000-0002-7112-8584

https://orcid.org/0000-0001-6772-3252

https://orcid.org/0000-0001-6496-0762

https://orcid.org/0000-0002-0588-8382

\section{References}

ABCB. (2016). Condensation in Buildings Handbook (2nd ed.). Canberra: Australian Government and States and Territories of Australia.

ABNT. (2013). NBR 15575-1 (Edificações habitacionais - Desempenho. Parte 1: Requisitos gerais). ABNT, Rio de Janeiro.

APA. (2017). Oriented Strand Board—Product Guide (No. W410E; p. 12). Washington: APA HEADQ. 
ASHRAE. (2016). ASHRAE 160 (Criteria for moisture-Control Design Analysis in buildings). ASHRAE Standards Committe, Atlanta, GA.

BSI. (1993a). BS EN 310 (Wood-based panels - Determination of modulus of elasticity in bending and of bending strength). British Standards Institution, UK.

BSI. (1993b). BS EN 319 (Particleboards and fibreboards: determination of tensile strength perpendicular to the plane of the board). British Standards Institution, London.

BSI. (2002a). BS EN 318 (Wood-based panels - Determination of dimensional changes associated with changes in relative humidity). British Standards Institution, UK.

BSI. (2002b). BSEN 321 (Wood-based panels - Determination of moisture resistance under cyclic test conditions). British Standards Institution, UK.

Campos, P. F. (2014). Light Steel Framing: Uso em construções habitacionais empregando a modelagem virtual como processo de projeto e planejamento (Dissertação (mestrado)). University of Sao Paulo, São Paulo.

CEN. (1993a). BS EN 323 (Wood-based panels - determination of density). Comité Européen De Normalisation, UK.

CEN. (1993b). EN 322 (Wood-based panels - Determination of moisture content). Comité Européen De Normalisation, Brussels.

Crasto, R. (2005). Arquitetura e Tecnologia em Sistemas construtivos Industrializados - Light Steel Framing (Dissertação (mestrado), Universidade Federal de Ouro Preto). Retrieved from http://www.repositorio.ufop.br/ handle/123456789/6246

DIN. (1993). DIN EN 317 (Particleboards and fibreboards: determination of swelling in thickness after immersion in water). Deutsches Institut für Normung, Berlin.

Kojima, Y. and Suzuki, S. (2011). Evaluating the durability of wood-based panels using internal bond strength results from accelerated aging treatments. Journal of Wood Science, 57(1), 7-13. https://doi.org/10.1007/ s10086-010-1131-4

Korai, H., Kojima, Y. and Suzuki, S. (2015). Bending strength and internal bond strength of wood-based boards subjected to various exp s10086-015-1494-7

Kumaran, M. K. (2009) Components. In M. Bom prevention (2nd ed, pl

Lstiburek, J. W. (2009).
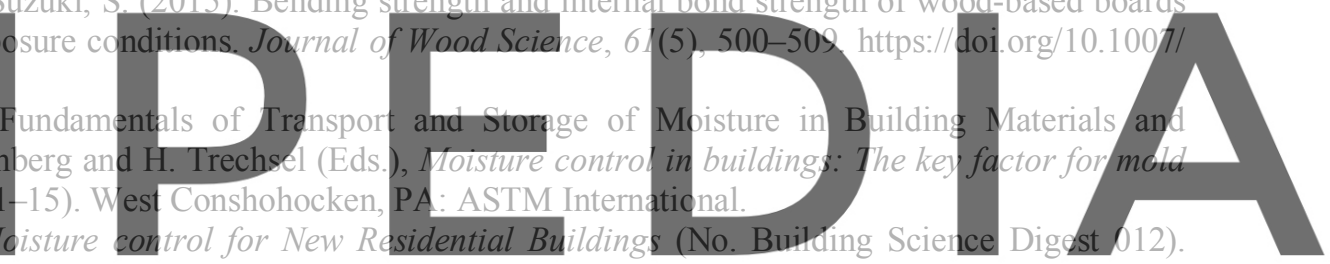
Somerville, MA: Building Science Corporation.

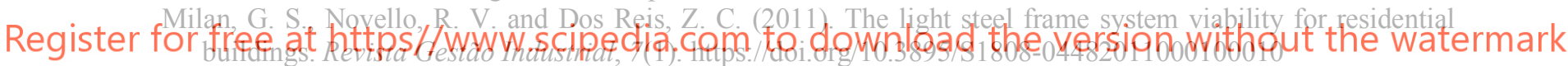

NRC. (2015). National Building Code of Canada. National Research Council

Okino, E. Y. A., Teixeira, D. E., de Souza, M. R., Santana, M. A. E. and de Sousa, M. E. (2004), Properties of oriented strandboard made of wood species from Brazilian planted forests: Part 1: $80 \mathrm{~mm}$-long strands of Pinus taeda L. Holz Als Roh- Und Werkstoff, 62(3), 221-224. https://doi.org/10.1007/s00107-004-0472-3

Oliveira, L. and Mitidieri Filho, C. (2011). Sistemas construtivos tipo light steel frame para unidades habitacionais-Aspectos relativos à durabilidade.pdf. Techne, (176), 78-83.

Quirouette, R. L. (1985). Building practice note n 54-The difference between a vapour barrier and an air barrier. Ottawa: NRCC.

Rego, D. (2012). Estruturas de Edificios em Light Steel Framing (Dissertação (mestrado), Universidade Técnica de Lisboa). Retrieved from https://fenix.tecnico.ulisboa.pt/downloadFile/395144743152/ MScThesis\%20 Diogo\%20Rego.pdf

SiNAT. (2016). Sistemas construtivos estruturados em perfis leves de aço zincado conformados a frio, com fechamentos em chapas delgadas (Sistemas leves tipo "Light Steel Framing”) (No. Diretriz SiNAT 003, rev 2). Retrieved from Ministério do Desenvolvimento Regional website: http://pbqp-h.cidades.gov.br/ projetos_sinat.php

Straube, J. F. (2002). Moisture in buildings. ASHRAE Journal, (January 2002), 5.

Tiba, C. (Ed.). (2000). Atlas Solarimetrico do Brasil-Banco de dados terrestres. Retrieved from http://www.cresesb.cepel.br/publicacoes/download/Atlas_Solarimetrico_do_Brasil_2000.pdf 